\title{
VI. 薬物性肝障害の治療と予後に関する諸問題
}

\section{川崎 寛中 村脇 義和}

\begin{abstract}
要旨
薬物性肝障害は通常起因薬物の投与を中止することにより速やかに改善するので, 薬物性肝 障害の治療にあたって最も重要なことは，でさるだけ早期に診断し，起因薬物の投与を中止す ることである．血液生化学検査でトランスアミナーゼの高值やビリルビンの上昇, プロトロン ビン時間の延長などがみられるときは入院を勧める。著明な肝実質障害を伴うものでは劇症化 へ移行する危険性があるので, 頻回に血液生化学検查を行って病態を的確に把握することが肝 要である.
\end{abstract}

〔日内会誌 $84 ： 211 \sim 215 ， 1995$ 〕

Key words : 薬物性肝障害, 治療, 予後

\section{はじめに}

薬物性肝障害の治療にあたって最も重要なこと は, 多くの薬物は薬物性肝障害を惹起する可能性 のあることを念頭におき，起因薬物の投与を可及 的速やかに中止することである．高度の肝細胞障 害例や胆汁うっ滞の遷延例, 急性肝不全例は入院 させて治療にあたる。本稿では薬物性肝障害の治 療および予後について，筆者らの成績を交えなが ら解説したいと思う。

\section{1. 一般的治療}

患者の臨床症状や肝機能障害が著しいときは安 静と十分な栄養補給が大切である。食事療法は比 較的糖質に富吉消化のよい食事を与え, 胆汁うつ 滞例では 1 日の脂肪を30〜 $40 \mathrm{~g}$ に制限する。全身 倦怠感, 食欲不振, 黄㾝が強く, 経口摂取が不十 分な場合は， 5〜10\%ブドウ糖500〜 $1000 \mathrm{ml}$ を補 給する. 胆汁うっ滞例でプロトロンビン時間の延 長がみられるときはビタミンK (ケーワン) $10 \mathrm{mg}$

鳥取大学医学部第二内科：かわさきひろなか, むら わきよしかず
を加える.日常臨床で多くを占める薬物アレル ギー性肝障害に対して強力ネオミノファーゲン シー (SNMC) 40ml静注療法が著効を示すことが ある。

\section{2. 薬物療法}

一般的治療を行っても胆汁うっ滞が遷延堌悪す る症例には表 1 に示すような薬物療法を行う。

\section{1）副腎皮質ホルモン}

副腎皮質ホルモンの肝内胆汁うっ滞に対する作 用機序として，抗炎症作用のほかに胆汁酸非依存 性胆汁流量を增やすことが知られている。この効 果は肝細胞膜の $\mathrm{Na}^{+}, \mathrm{K}^{+}$.ATPaseの活性化によっ て態動輸送障害を改善するためである。また副腎 皮質ホルモンの投与により, cholesterol $7 \alpha$ hydroxylase活性の増加による胆汁酸生成え進や 硫酸抱合型胆汁酸の低下作用なども明らかにされ ている゙。.

副腎皮質ホルモンの一般的な投与方法は，1日 30〜40mgのプレドニゾロン投与で開始して 5 日 抢きに $5 \mathrm{mg}$ ずつ漸減し, 臨床症状, 検査所見を参考 にしながら経過を観察する。無効例については早 期に投与を中止する. 
表 1。肝内胆汁うっ滞に対する薬物療法

1. 副筒皮筫ホルモン

プレドニソロン $30 \sim 40 \mathrm{mg} /$ 日で開始して濑滅療 法を行う

2. ウルソデオキシコール酸(UDCA)

$150 \sim 600 \mathrm{mg} /$ 日

3.フェノバルビタール

$60 \sim 200 \mathrm{mg} /$ 日

4. コレスチラミン

6〜12g/日

5.アミノエチルスルホン酸 $3 \mathrm{~g} /$ 日

6. セクレチン

100 150U点滴静注

7. S-アデノシル-L-メチオニン(SAMe)

200 1,200mg点滴静注

8. 硫酸マグネシウム注入療法(Meltzer-Lyon法) 十二指腸ゾンデを通じて33\%硫酸マグネシウム 液 $40 \mathrm{ml}$ 注入する

9. 脂溶性ビタミン薬, カルシウム薬

図 1 はチオプロニン (チオラ®)による薬物性肝 炎に再生不良性䝷血を合併した興味ある症例の臨 床経過を示している。症例は平成 6 年 7 月 15 日よ りアルコール性肝障害でチオプロニン $300 \mathrm{mg} /$ 日 を服用していたが，8月12日血清ビリルビン， ALP，ASTの著明な上昇を認め，チオプロニンに よる薬物性肝障害が疑われ薬物の投与が中止され た. 中止後血清ビリルビン, ASTは減少傾向を示 したが, 中止 2 週間後より貧血, 白血球数の減少, 骨铕像で赤芽球系，顆粒球系の著減を認め再生不 良性筫血と診断した.この頃発熱が出現したため, 顆粒球コロニー刺激因子グラン投与によりまず白 血球数を增加させた後,プレドニゾロンを投与し， 貧血および肝障害の改善を認めた。

2) ウルソデオキシコール酸

ウルソデオキシコール酸 (ursodeoxycholic acid；UDCA）は古くから利胆薬やコレステロー ル系胆石の溶解薬として用いられてきた。近年, UDCA は原発性胆汁性肝硬変 $(\mathrm{PBC})$, 原発性硬化 性胆管炎 (PSC)，遷延性の急性肝内胆汁うっ滞， 慢性肝炎などの治療薬として脚光を浴びている。 UDCA は比較的親水性胆汁酸であり, 肝内胆汁 うっ滞に対する作用機序としては，利胆作用のほ
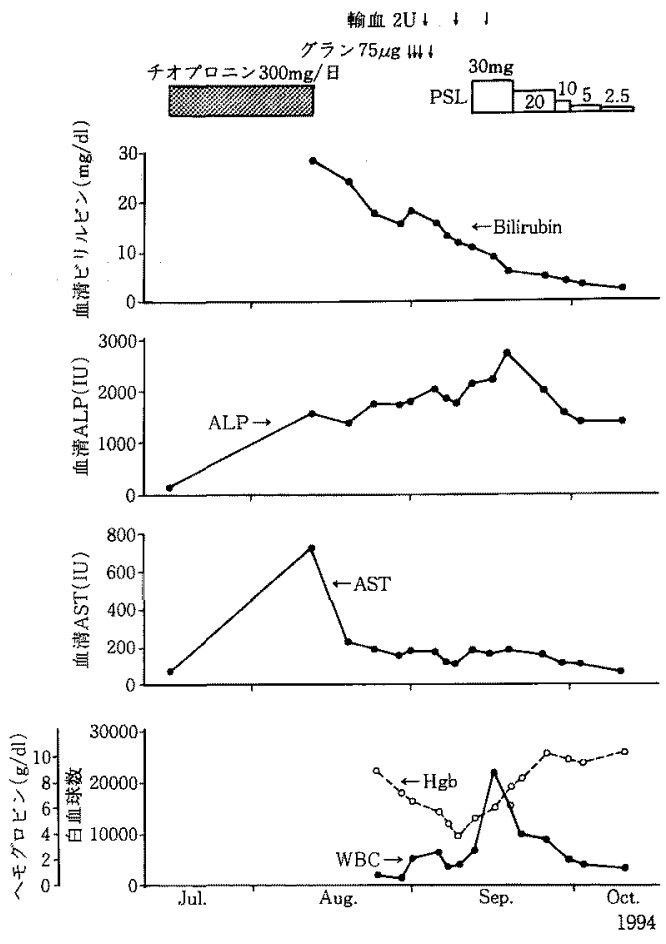

図 1，チオプロニンによる薬物性肝炎 (症例No. 012-2405-0，62墄，男性）の臨床経過

かに, 肝細胞障害性胆汁酸（ケノデオキシコール 酸，デオキシコール酸，コール酸など）置換によ る肝細胞保護作用, 肝血流量增加作用, 免疫調節 作用, 肝細胞内カルシウム調節作用などが考えら れている。UDCAの免疫調節作用は多方面から研 究されているが, UDCAの直接作用か, UDCAの 解毒作用による間接効果かはいまだ不明であ $ろ^{2)}$.

UDCA は 1 日150〜 600 $\mathrm{mg}$ を経口投与する. UDCA療法の効果としては, 血清ビリルビンの低 下のほか, 胆道系酵素, トランスアミナーゼの低 下や，皮膚瘙痒の改善がみられる．副作用は殆ど 認められない. 自験例では薬物性肝内胆汁うっ滞 の 6 例中 5 例に効果を認めている.UDCA投与後 の血清胆汁酸分画ではコール酸とケノデオキシ コール酸の低下がみられ，代わりにUDCAの増加 が認められる。 

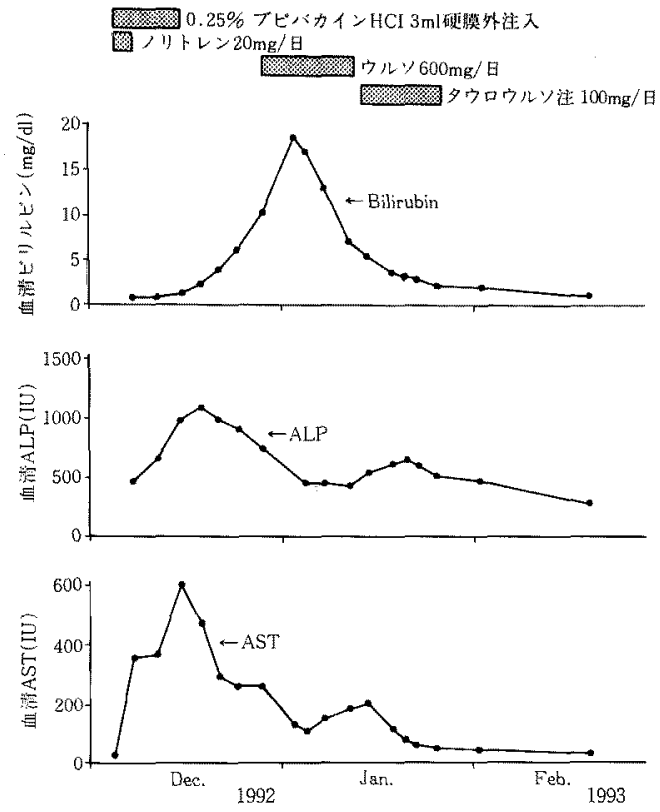

図 2、ブピバカイン塩酸塩による薬物性肝炎（症例 No. 926141，71歳, 女性）に対するUDCA療法

図 2 はブピバカイン塩酸塩 (マーカイン®)によ る薬物性肝炎の臨床経過を示す，症例は带状疱疹 後の神経痛に対して，マーカインの硬膜外注入， ノリトレン®の投与を受けた。治療開始 3 日後の 肝機能検查でALP, ASTの上昇が認められ，ノリ トレン®を中止したが，ALP，ASTの上昇が続く ためマーカイン®による薬物性肝障害を疑い中止 した、マーカインは止後ASTは急速に低下した が，血清ビリルビン，ALPの上昇が続くため，ウ ルソ®600 $\mathrm{mg} /$ 日の内服, その後タウロウルソデオ キシコール酸100mg/日静注により,肝障害は順調 に改善した。

\section{3）フェノバルビタール}

遷延する胆汁うっ㴖にフェノバルビタールを投 与すると, 症例によっては皮膚癌痒の軽隇ととも に血清ビリルビンの低下が認められる.フェノバ ルビタールの作用機序として, 胆汁酸非依存性胆 汁流量の増加のほかに, チトクロームP-450誘導効 果による胆汁酸水酸化の亢進があげられる。また フェノバルビタールは肝血流量増加, 肝リガンジ
ン増加, UDP-glucuronyl transferase誘導, 胆汁 酸のグルクロン酸抱合え進などに作用する.

薬物性肝内胆汁うっ滞に対し, 通常フェノバル ビタール60〜200mg/日，2 週間前後投与する. 有 効例は血清胆汁酸が低下して皮膚疼㾕の軽隇効果 が認められることが多い.フェノバルビタールの 無効例に対しては早期に投薬を中止する。

\section{4) コレスチラミン}

陰イオン交換樹脂のコレスチラミンは皮膚瘦痒 に対して有效で，抗七スタミン薬と併用すること が多い、コレスチラミンは消化管内の胆汁酸を吸 着して腸肝循環を遮断するために, 肝細胞内の胆 汁酸合成穴進に上る胆汁酸依存性胆汁流量が增加 する。

コレスチラミン 6〜 $12 \mathrm{~g} /$ 日を経口投与する、コ レスチラミンはカルシウム, 脂溶性ビタミン, ジ ギトキシンなどと容易に結合するので，コレスチ ラミンとほかの薬物は時間をおいて服用させる必 要がある. 便秘, 胃晹症状, 発疹, 紅潮, 熱感, めまい, 耳鳴, 口腔内アフタ, 歯肉腫脹などの副 作用に注意する。

\section{5）アミノエチルスルホン酸}

アミノエチルスルホン酸 (タウリン®) は胆汁分 泌促進作用, 肝細胞賦活作用, 肝細胞膜保護作用 などを有する．通常，1日3gを経口投与して臨床 経過を観察するが，UDCAとの併用処方がよく用 いられる。

\section{6) セクレチン}

消化管ホルモンの1つであるセクレチンは細胆 管レベルで水, 重炭酸, クロールの分泌を促進す る。副腎皮質ホルモンやフェノバルビタール無効 例に対して，セクレチン 1 日100〜150単位を $5 \%$ ブドウ糖または生理食塩水 $250 \mathrm{ml}$ に溶解して点滴 静注する3).

\section{7）S-アデノシル-L-メチオニン}

S-adenosyl-L-methionine (SAMe) の一般名は アデメチオニンと呼ばれ，生体内のメチル化反応 のメチル基供与体として重要な役割を演じてい る.アデメチオニンは $\mathrm{Na}^{+}, \mathrm{K}^{+}$-ATPase活性の増 加と膜のりン脂質組成を変えることによって膜の 安定化作用を有する。外国の報告では妊娠性朋内 
胆汁うっ滞や, 慢性肝炎, 肝硬変, $\mathrm{PBC}$ に伴った 肝内䏣汁うっ滞, 薬物性肝障害などに対して有効 性が認められる21.

8）硫酸マグネシウム注入療法 (Meltzer-Lyon 法)

古くから臨床的に用いられている方法で，33\% 硫酸マグネシウム液を十二指腸ゾンデを通じて注 入することにより，胆䨢が取縮するとともにOddi 筋が開いて排胆効果を得るものである。本法は 種々の薬物療法に抵抗する肝内胆汁うっ滞に対し て，あるいは薬物療法に並行して用いられる。

\section{9）脂溶性ビタミン薬，カルシウム薬}

胆汁うっ滞が長期にわたって遷延する場合に は，ビタミンA 10万単位，ビタミンD 10万単位， ビタミンK 10mgを 4 週ごとに筋肉注射で補う。 胆汁うっ滞でカルシウムの不足時にはグルコン酸 カルシウム $3 \mathrm{~g} /$ 日を経口的に投与する。

\section{3. 劇症化への対策}

薬物性肝障害のうち胆汁うっ滞型では黄疸が著 明であっても劇症化することは殆どないが，肝細 胞障害型では劇症化する症例がある，劇症化の判 定には, 急性ウイルス肝炎と同様に, 臨床所見や, 血清ビリルビン, 血液凝固因子,トランスアミナー ゼ, ChE (cholinesterase), LCAT (lecitincholesterol acyltransferase) などの検查所見で評 価する，血清ビリルビンの著明な上昇，プロトロ ンビンやへパプラスチンテストの著明な低下，肝 性脳症の出現は, 劇症化の有力な指標である.

急性肝不全と診断した場合には，劇症肝炎の治 療に準じて，血漿交換，グルカゴン・インスリン 療法をはじめとする特殊治療を行うとともに，生 命徴候のチェック, 輸液の管理, 電解質の維持な どの全身管理を厳重に行うことが大切である。ま た, 脳浮腫, 消化管出血, 急性腎不全, DIC (disseminated intravasculer coagulation) などの致 命的な合併症が出現する可能性が高いので，早期 に診断するとともに，グリセオール， $\mathrm{H}_{2}$ ブロッ カー, 血液透析, アンチトロンビンIII製剤などで 積極的に治療を行う必要がある。
薬物性肝障害のうち，しばしば急性肝不全をき たすものとして，アセトアミノフェン肝障害があ げられる。たた゚アセトアミノフェン肝障害では， 肝不全への進展を予防する治療法が確立されてい る。本薬物の肝毒性は過㮃服用によりチトクロー 厶P-450（P450IIE1，P450IA2）で活性代謝産物 $\mathrm{N}$-acetyl-p-benzoimidoquinone (NAPIQ) が過剩 に生成され，肝細胞内グルタチオンが枯渴し， NAPIQが肝高分子蛋白と結合するため，肝細胞 壇死を生じると考えられている。したがって，肝 細胞内グルタチオン量を保持することができれば 肝細胞障害を予防することができる、グルタチオ ンの補給には，前駆体であるL-システイン，L-メ チオニン，N-アセチルシステインなどが使用され てきたが，このうち最も効果的で副作用が少ない のはN-アセチルシステインである.

アセトアミノフェン過剩服用患者に対する具体 的治療法としては，服用直後であれば通常の薬物 と同様に胃洗浄を行うが，できるだけ早い時期よ りN-アセチルシステイン（日本では気道粘液溶解 用吸入液として発売されている）を体重 $1 \mathrm{~kg}$ 当り $140 \mathrm{mg}$ 経口的にまず投与し，以後 1 時間毎に70 $\mathrm{mg} / \mathrm{kg}$ を繰り返し投与する。この間に血清アセ卜 アミノフェン濃度（ダイナボット社より測定試薬

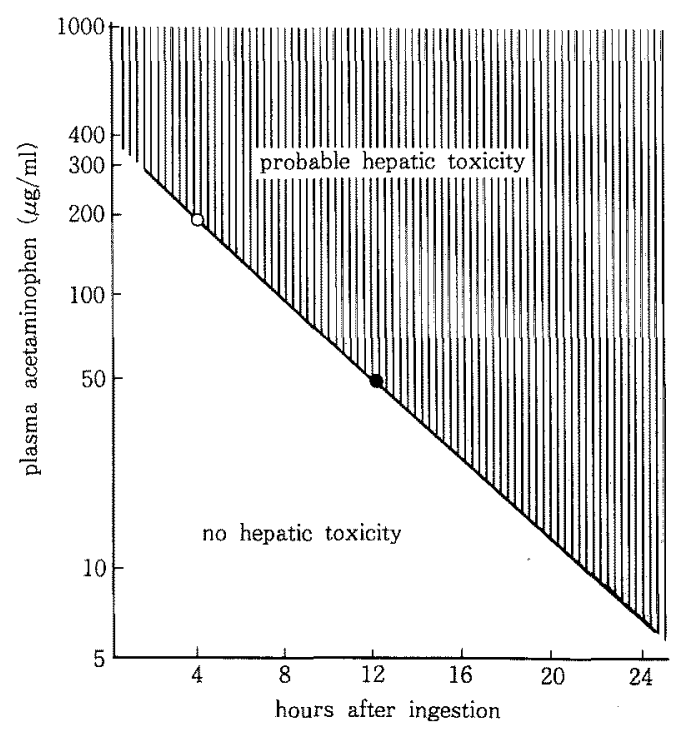

図 3．血中アセトアミノフェン濃度と肝障害との関係 


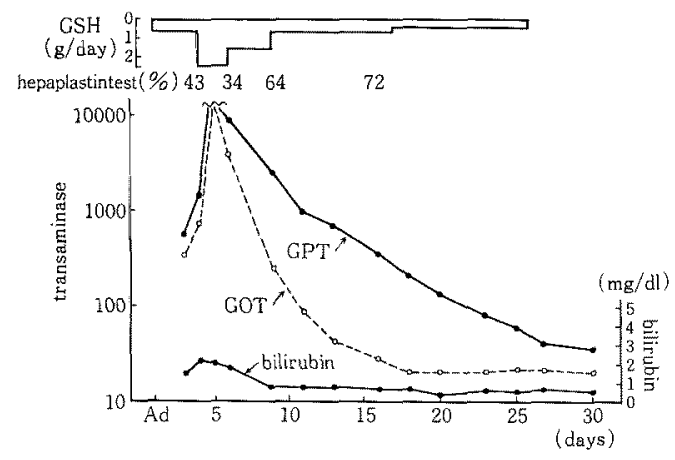

図4，アセトアミノフェン肝炎の1 例

が発売されている）を測定し，血清中濃度が肝毒 性を示さない濃度以下になれば投与を中止する。

肝毒性を示さない濃度は，内服 4 時間での $200 \mu \mathrm{g}$ / $\mathrm{ml}$ と内服12時間での $50 \mu \mathrm{g} / \mathrm{ml}$ と結んだ直線以 下である(図 3 )。また，その発症機序より薬物代 謝系の抑制作用を有するシメチジンの投与も有用 である。

筆者らは22歳女性で自殺目的でセデスA60錠を 服用し，急性肝不全をきたした症例を経験したが， 本症例では早期よりグルタチオン (GSH) 1〜2gの 点滴投与を行った (図 4$)^{4}$. 一一般にグルタチオン はぺプチドであるため肝細胞内への移行が少な く，アセトアミノフェンによる肝障害を予防する 効果は少ないとされているが，本例ではある程度 有効であった可能性がある。

\section{4. 予後}

薬物性肝障害は起因薬物の中止により速やかに 回復し，一般にその予後は良好であるが，肝細胞 障害型では急性肝不全に進行する例, 胆汁うっ滞 型では黄疸が数力月にわたつて僄延する例がまれ にある。重症化抢よび遷延化する症例では，肝障 害発症後も起因薬物が長期に継続されていた場合
や反復投与された場合が多い，通常，薬物性肝障 害薬物投与開始 2 力月以内に発症することが多 いので，この間峐薬物性肝障害を念頭におき肝機 能をチェックすることが肝要である。

アセトアミノフェン肝障害では, 過剰服用後 10 時間以内にNーアセチルシステイン療法が行えた 場合，重篤な肝障害を予防でき予後は良好である が，肝壊死を生じた場合の予後は肝不全の重症度 に依存する。具体的には，血清ビリルビンが $4 \mathrm{mg} /$ mIl上, プロトロビン時間が正常値の二倍以上, 招よび肝性脳症を呈する症例では死亡率30\%以上 とされている.

\section{おわりに}

薬物性肝障害の治療にあたって最も重要なこと は，できるだけ早期に診断し，起因薬物の投与を 中止することである. 薬物性肝障害, 特に肝内胆 汁うっ滞の治療薬として，まず副腎皮質ホルモン とUDCAがあげられ, 後者は多彩な作用機序の解 明とともに今後広く用いられそうである。胆汁 うっ滞の遷延例に対する薬物療法は個々の症例に より治療効果が異なるので，無効な薬物をいたず らに長期に使わないようにする。一方, 薬物によ る急性肝不全では，患者の全身管理を厳重に行っ て劇症肝炎に準じた治療で経過を観察する。

\section{文献}

1）川䗁寬中，他：肝内胆汁うっ滞に対する内科的治 療薬剂の作用機序一特に胆汁酸代謝からの検討。 肝臟 $27: 1503,1986$.

2) Reichen J: Pharmacologic treatment of cholestasis. Sem Liver Dis 13: 302, 1993.

3) Fukumoto $Y$, et al: A new therapeutic trial of secretin in the treatment of intrahepatic cholestasis. Gastroenterol Jpn $24: 298,1989$.

4）涌島 正，他：アセトアミノフェン肝炎の1例。 肝臓 $24: 1411,1983$. 